\title{
DETERMINATION OF THE FRACTION OF GIBBSITE AND BOEHMITE FORMS OF ALUMINUM IN TANK 51H SLUDGE
}

August 2008

Waste Processing Technology Section Savannah River National Laboratory Aiken, SC 29808 


\section{DISCLAIMER}

This work was prepared under an agreement with and funded by the U.S. Government. Neither the U. S. Government or its employees, nor any of its contractors, subcontractors or their employees, makes any express or implied: 1 . warranty or assumes any legal liability for the accuracy, completeness, or for the use or results of such use of any information, product, or process disclosed; or 2. representation that such use or results of such use would not infringe privately owned rights; or 3. endorsement or recommendation of any specifically identified commercial product, process, or service. Any views and opinions of authors expressed in this work do not necessarily state or reflect those of the United States Government, or its contractors, or subcontractors.

This document was prepared in conjunction with work accomplished under Contract No. DE-AC09-08SR22470 with the U.S. Department of Energy.

\section{Printed in the United States of America \\ Prepared For U.S. Department of Energy}


Key Words:

Sludge Analysis

Aluminum Dissolution

Sludge Mass Reduction

\title{
Retention: Permanent
}

\section{Key References:}

Technical Task Request: HLE-TTR-2007-018, Rev. 1 Technical Task Plan: WSRC-TR-2007-00176, Rev. 0

\section{DETERMINATION OF THE FRACTION OF GIBBSITE AND BOEHMITE FORMS OF ALUMINUM IN TANK 51H SLUDGE}

\author{
M. S. Hay, SRNL/A\&CPT \\ K. Adu-Wusu, SRNL/A\&CPT \\ D. J. McCabe, SRNL/A\&CPT
}

Issue Date: August 2008

Waste Processing Technology Section Savannah River National Laboratory Aiken, SC 29808

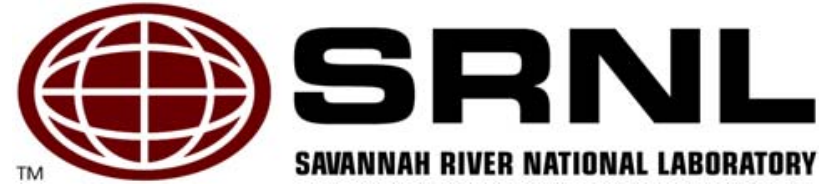




\section{REVIEWS AND APPROVALS}

M. S. Hay, Author, SRNL/A\&CPT

Date

K. Adu-Wusu, Author, SRNL/A\&CPT

D. J. McCabe, Author, Manager SRNL/A\&CPT

C. J. Martino, Technical Reviewer, SRNL/ A\&CPT

J. Stuberfield, Project Owner, Technology Development and Tank Closure
Date

Date

Date
Date 


\section{TABLE OF CONTENTS}

List of Tables $\quad$ iv

List of Figures $\quad$ iv

$\begin{array}{ll}\text { List of Acronyms } & \mathbf{v}\end{array}$

SUMMARY vi

$\begin{array}{ll}1.0 \text { INTRODUCTION } & 1\end{array}$

2.0 DESCRIPTION OF MATERIALS AND TEST PROCEDURE 2

2.1 Sludge SAMPle Description ANd PREPARATION FOR TESTING

2.2 PREPARATION OF STANDARDS FOR TEST

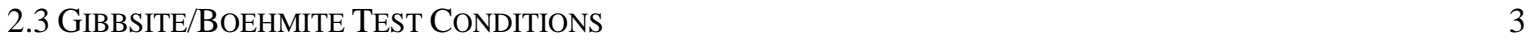

2.4 PREPARATION OF SAMPLES FOR ANALYSIS 3

\section{$\begin{array}{lc}\text { 3.0 RESULTS AND DISSCUSSION } & 4\end{array}$}

3.1 CHARACTERIZATION OF THE INITIAL SLUDGE SAMPLE

3.2 RESUltS OF THE GIBBSITE/BOEHMITE TEST

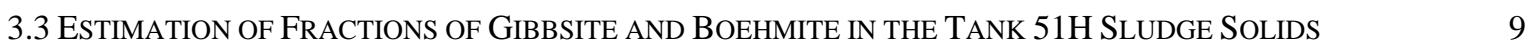

3.4 CONCLUSIONS 9

$\begin{array}{ll}\text { 4.0 REFERENCES } & 11\end{array}$ 


\section{List of Tables}

TABLE 2-1. GIBBSITE/BoEHMiTE STANDARDS …………..........................................................................

TABle 3-1. Weight Percent Solids and Density of the Initial TANK 51H Composite Sludge Slurry SAMPLE AND THE ORIGINAL 3-L SLUDGE SLURRY SAMPLE ...........................................................

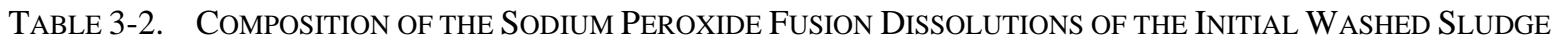

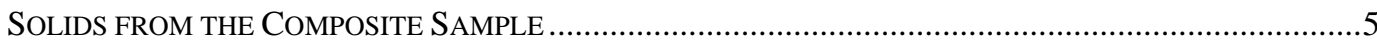

TABle 3-3. COMPARISON OF THE NORMALIZED COMPOSITION OF WASHED SOLIDS FROM THE COMPOSITE

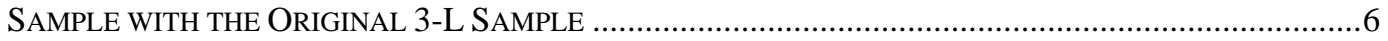

TABLE 3-4. MASS OF AluminUm IN THE SLUdGe SOLIDS AND STANDARDS .......................................................6

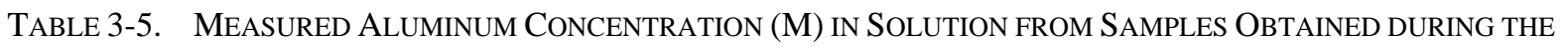
GIBBSITE/BOEHMITE TEST ........................................................................................................

TABle 3-6. The Normalized Composition of WASHEd Sludge SolidS FROM the GibBSite/BoeHMite

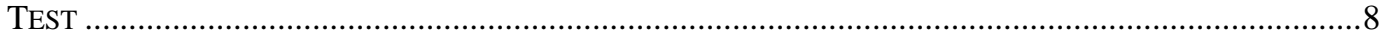

\section{List of Figures}

Figure 3.1 Aluminum Concentration as a Function of Time during The GibBsite/Boehmite Test....8 


\section{List of Acronyms}

$\begin{array}{ll}\text { SRS } & \text { Savannah River Site } \\ \text { LWO } & \text { Liquid Waste Organization } \\ \text { LTAD } & \text { Low Temperature Aluminum Dissolution } \\ \text { DWPF } & \text { Defense Waste Processing Facility } \\ \text { SRNL } & \text { Savannah River National Laboratory } \\ \text { AD } & \text { Analytical Development } \\ \text { ICP-ES } & \text { Inductively Couple Plasma-Emission Spectroscopy }\end{array}$




\section{SUMMARY}

The Savannah River National Laboratory (SRNL) was tasked with developing a test to determine the fraction of the gibbsite and boehmite forms of aluminum in the sludge solids. Knowledge of the fractions of gibbsite and boehmite in the sludge contained in various waste tanks would facilitate better sludge mass reduction estimates and allow better planning/scheduling for sludge batch preparation.

The composite sludge sample prepared for use in the test from several small samples remaining from the original 3-L sample appears to be representative of the original sample based on the characterization data.

A Gibbsite/Boehmite Test was developed that uses $8 \mathrm{M} \mathrm{NaOH}$ and a temperature of $65^{\circ} \mathrm{C}$ to dissolve aluminum. The soluble aluminum concentration data collected during the test indicates that, for the three standards containing gibbsite, all of the gibbsite dissolved in approximately 2 hours. Under the test conditions boehmite dissolved at more than an order of magnitude more slowly than gibbsite. An estimate based on the soluble aluminum concentration from the sludge sample at two hours into the test indicates the sludge solids contain a form of aluminum that dissolves at a rate similar to the $100 \%$ Boehmite standard. Combined with the XRD data from the original 3-L sample ${ }^{2}$, these results provide substantial evidence that the boehmite form of aluminum predominates in the sludge. A calculation from the results of the Gibbsite/Boehmite test indicates the sludge contains $\sim 3 \%$ gibbsite and $\sim 97 \%$ boehmite.

The sludge waste in Tank 51H was recently treated under Low Temperature Aluminum Dissolution (LTAD) conditions and a substantial fraction of aluminum (i.e., sludge mass) was removed, avoiding production of over 100 glass canisters in Defense Waste Processing Facility (DWPF). Results of the Gibbsite/Boehmite test indicate that the aluminum in this sludge was in the form of the more difficult to dissolve boehmite form of aluminum. Since boehmite may be the dominant form of aluminum in Savannah River Site (SRS) waste tank sludge, this result suggests that the conditions of the LTAD process can be used to dissolve both the gibbsite and boehmite forms of aluminum in tank sludge and costly tank infrastructure upgrades required for the higher temperature baseline process can be avoided. However, this conclusion should be confirmed by testing additional waste tank samples. 
WSRC-STI-2008-00366, REV. 0

\subsection{INTRODUCTION}

The SRS Liquid Waste Organization (LWO) recently used caustic to dissolve aluminum in a Low Temperature Aluminum Dissolution (LTAD) process ${ }^{1}$. The LTAD process reduces the total mass of sludge solids being fed to the DWPF. Of the three predominant forms of aluminum believed to be present in the sludge solids, aluminum trihydrate (gibbsite), aluminum monohydrate (boehmite), and aluminosilicates, only the gibbsite form was expected to dissolve under the conditions of the LTAD process. Historical documents at SRS dealing with sludge processing generally assume that the gibbsite form of aluminum accounts for $\sim 75 \%$ of the aluminum in sludge. The recent treatment of sludge waste in Tank $51 \mathrm{H}$ under LTAD conditions dissolved a substantial fraction of aluminum avoiding production of over 100 glass canisters in DWPF. These dissolution conditions of the LTAD process were compatible with existing waste tank infrastructure, and tank upgrades to accommodate the higher temperature conditions of the baseline process ${ }^{2}$ were avoided.

In Tank $51 \mathrm{H}$ (Sludge Batch 5), the LTAD process contacted the sludge with $\sim 4 \mathrm{M} \mathrm{NaOH}$ for a period of 46 days with the temperature maintained between $55^{\circ} \mathrm{C}$ and $65^{\circ} \mathrm{C}$. Results show that $57-64 \%$ of the aluminum in the sludge solids dissolved. ${ }^{1}$ A demonstration of the LTAD process in the SRNL with a 3-L sample of the Tank $51 \mathrm{H}$ sludge found $\sim 40 \%$ of the aluminum dissolved using $\sim 4 \mathrm{M} \mathrm{NaOH}$ at $55^{\circ} \mathrm{C}$ for 21 days. ${ }^{3}$ Both results indicate a much slower dissolution rate than expected if the gibbsite form of aluminum predominates in the sludge. The slow dissolution rate and x-ray diffraction (XRD) data from the characterization of the 3-L sample suggest that boehmite could be the predominant form of aluminum in the sludge solids for this sludge batch.

SRNL was tasked with developing a test to determine the fraction of the gibbsite and boehmite forms of aluminum in the sludge solids. A wet assay method for measuring gibbsite and boehmite was communicated to SRNL from a consultant. ${ }^{4}$ However; this method was not viable for radioactive samples at SRNL because of the requirement to heat the sample in a high pressure autoclave. A test requiring only mild temperatures and pressures would be more amenable to use in the Shielded Cells.

Knowledge of the fractions of gibbsite and boehmite in the sludge contained in various waste tanks would facilitate better sludge mass reduction estimates and allow better planning/scheduling for sludge batch preparation. A Technical Task Request ${ }^{5}$ and a Task Technical and Quality Assurance Plan' ${ }^{6}$ were generated for the task. 


\subsection{DESCRIPTION OF MATERIALS AND TEST PROCEDURE}

\subsection{SLUDGE SAMPLE DESCRIPTION AND PREPARATION FOR TESTING}

Several small samples of sludge remaining from a 3-L sludge sample from Tank 51H (ID No. $=$ HTF-51-07-77) were combined to provide material for the test. The 3-L sludge sample was used in the recent aluminum dissolution demonstration in the Shielded Cells. ${ }^{3}$ The composite sludge sample used in the Gibbsite/Boehmite Test had not been subjected to the aluminum dissolution process. The weight percent total solids and density of the composite sludge sample were measured prior to starting the test. Approximately $45 \mathrm{ml}$ of the sludge sample was filtered through a $0.45 \mu \mathrm{m}$ nylon filter. The sludge solids remaining on the filter were washed four times with an equal volume of $0.01 \mathrm{M} \mathrm{NaOH}$ to displace the interstitial supernate. A small portion of the damp sludge solids was immediately used in the Gibbsite/Boehmite Test (see Section 2.3). The remaining washed sludge solids were dried in an oven at $100{ }^{\circ} \mathrm{C}$ to determine the moisture content and provide material for sample characterization. The damp sludge solids used in the test were found to contain $44 \mathrm{wt} \%$ solids (56 wt\% water).

\subsection{PREPARATION OF STANDARDS FOR TEST}

Four standards were prepared for use in the Gibbsite/Boehmite Test. The standards included a 100\% Gibbsite standard, a 75\% Gibbsite/25\% Boehmite standard, a 25\% Gibbsite/75\% Boehmite standard and a 100\% Boehmite standard. Table 2.1 shows actual weights of Gibbsite and Boehmite used in each standard. Each of the standards contains the approximately the same total mass of material. The $75 \%$ Gibbsite standard therefore contains $\sim 75 \%$ as much gibbsite as the $100 \%$ Gibbsite standard. The gibbsite and boehmite were analyzed previously and found to be essentially pure. ${ }^{7}$

Table 2-1. Gibbsite/Boehmite Standards

\begin{tabular}{|l|c|c|}
\hline Standard & $\begin{array}{c}\text { Wt of } \\
\text { Gibbsite }^{\mathbf{a}} \text { (g) }\end{array}$ & $\begin{array}{c}\text { Wt of } \\
\text { Boehmite }^{\mathbf{b}} \text { (g) }\end{array}$ \\
\hline 100\% Gibbsite & 0.900 & - \\
\hline 75\% Gibbsite/25\% Boehmite & 0.681 & 0.221 \\
\hline 25\% Gibbsite/75\% Boehmite & 0.220 & 0.681 \\
\hline 100\% Boehmite & - & 0.900 \\
\hline
\end{tabular}

a Gibbsite, Hydrated Alumina ATH C333, Almatis Inc

b Boehmite, HiQ-B180, BASF Catalysts LLC 


\subsection{GIBBSITE/BOEHMITE TEST CONDITIONS}

Cold bench-top tests were conducted using pure gibbsite, pure boehmite and various mixtures of gibbsite and boehmite to determine conditions that dissolve gibbsite within 1-3 hours at moderate temperatures $\left(<85^{\circ} \mathrm{C}\right)$ with minimal dissolution of boehmite. After numerous trials, a ratio of $\sim 0.3 \mathrm{~g}$ of gibbsite $(\sim 0.1 \mathrm{~g} \mathrm{Al})$ to $16 \mathrm{ml}$ of $8 \mathrm{M} \mathrm{NaOH}$ at $65{ }^{\circ} \mathrm{C}$ was found to dissolve all of the gibbsite in $\sim 2$ hours. At these conditions the rate of boehmite dissolution was quite low.

In order to provide sufficient material for sampling during the test, the quantities established above were tripled to $\sim 0.3 \mathrm{~g}$ of Al to $50 \mathrm{ml}$ of $8 \mathrm{M} \mathrm{NaOH}$. Each of the standards shown in Table 2.1 was weighed into a $125 \mathrm{ml}$ poly bottle providing $\sim 0.3 \mathrm{~g}$ of $\mathrm{Al}$ in each bottle. The damp washed sludge solids were assumed to be approximately 50\% water (determined after the test to be $56 \%$ water). Based on the previous analysis ${ }^{3}$, the washed sludge solids were expected to contain $\sim 25 \mathrm{wt} \% \mathrm{Al}$. Therefore, $2.465 \mathrm{~g}$ of the damp sludge solids were weighed into a $125 \mathrm{ml}$ poly bottle providing $\sim 0.3 \mathrm{~g}$ of $\mathrm{Al}$.

A graduated cylinder was used to add $50 \mathrm{ml}$ of $8 \mathrm{M} \mathrm{NaOH}$ to each of the five bottles (4 standards and 1 sludge sample). The bottles were shaken to thoroughly mix the solids and sodium hydroxide solution. A $2 \mathrm{ml}$ aliquot was removed from each bottle and placed in a 10 $\mathrm{ml}$ syringe fitted with a $0.45 \mu$ nylon filter cartridge. Each solution was filtered through a syringe filter into a bottle containing $13 \mathrm{ml}$ of $3 \mathrm{M}$ nitric acid. These samples represent the time zero samples for the test. The five bottles were placed in a shaker oven set $65{ }^{\circ} \mathrm{C}$. The start times of each bottle were staggered at five-minute intervals to allow time for sample collection and minimize time outside of the oven. At half hour intervals, each bottle was removed from the oven and a $2 \mathrm{ml}$ aliquot filtered into a bottle containing $13 \mathrm{ml}$ of $3 \mathrm{M}$ nitric acid. Visual observations showed the bottle containing 100\% Gibbsite was essentially clear at 1.5 hours. The test was continued for 4 hours collecting samples from each bottle every 30 minutes.

After collecting the final samples at four hours after starting the test, the sludge sample was filtered through a $0.45 \mu$ nylon filter and the solids washed four times with an equal volume of $0.01 \mathrm{M} \mathrm{NaOH}$ to displace the interstitial liquid. The washed sludge solids were dried to determine the $\mathrm{wt} \%$ solids and provide material for characterization.

\subsection{PREPARATION OF SAMPLES FOR ANALYSIS}

The nitric acid solutions of samples collected during the test were submitted to Analytical Development (AD) for determination of the aluminum concentration by Inductively Coupled Plasma-Emission Spectroscopy (ICP-ES).

The dried sludge solids from the initial sludge solids used in the test and from the solids remaining after the Gibbsite/Boehmite Test were prepared for analysis by dissolution using the sodium peroxide fusion method. The dissolved material was sent to AD for determination of the aluminum concentration by ICP-ES. 


\subsection{RESULTS AND DISSCUSSION}

\subsection{CHARACTERIZATION OF THE INITIAL SLUDGE SAMPLE}

Table 3-1 shows the results from the measurement of the weight percent solids and density of the initial composite sludge sample. The results from the composite sample used for the Gibbsite/Boehmite test show reasonable agreement with the measurements from the original 3-L sludge slurry sample. ${ }^{3}$ The composite sample appears to be slightly more concentrated than the original 3-L sample based on the weight percent solids measurements.

Table 3-1. Weight Percent Solids and Density of the Initial Tank 51H Composite Sludge Slurry Sample and the Original 3-L Sludge Slurry Sample

\begin{tabular}{|l|c|c|c|}
\hline Analyte (Method) & Units & $\begin{array}{c}\text { Composite } \\
\text { Sample } \\
\text { Average }\end{array}$ & $\begin{array}{c}\text { Original 3-L } \\
\text { Sample } \\
\text { Average }^{\text {d }}\end{array}$ \\
\hline Weight Percent Total Solids & $\mathrm{Wt} \%$ & $16.1 \%^{\mathrm{a}}$ & $15.5 \%$ \\
\hline Weight Percent Dissolved Solids & $\mathrm{Wt} \%$ & $7.16 \%^{\mathrm{b}}$ & $6.75 \%$ \\
\hline Weight Percent Soluble Solids & $\mathrm{Wt} \%$ & $6.47 \%^{\mathrm{c}}$ & $6.12 \%$ \\
\hline Weight Percent Insoluble Solids & $\mathrm{Wt} \%$ & $9.64 \%^{\mathrm{c}}$ & $9.39 \%$ \\
\hline Density of Slurry & $\mathrm{g} / \mathrm{ml}$ & $1.07^{\mathrm{a}}$ & 1.08 \\
\hline Density of Supernate & $\mathrm{g} / \mathrm{ml}$ & $1.04^{\mathrm{b}}$ & 1.06 \\
\hline
\end{tabular}

a Value shows the result of a single measurement.

b Value represents the average of two or more determinations.

c Values for the weight percent soluble solids and weight percent insoluble solids were calculated from the measured weight percent total solids and weight percent dissolved solids.

d Data taken from Reference 3

After filtration and washing, the remaining solids from the composite sludge sample not used in the Gibbsite/Boehmite test were dried and dissolved for analysis. The damp sludge solids used in the test were found to contain $44 \mathrm{wt} \%$ solids (56 wt\% water). Table 3-2 shows the result of the analysis of the washed sludge solids from the composite sample. A direct comparison to the composition of the original 3-L sample cannot be made since the solids from the composite sample were washed. However, after normalizing the main components of the sludge solids to iron, a comparison of the composite sample and the original 3-L sample indicates a similar composition for the two samples (see Table 3-3). In contrast, the $\mathrm{Al} / \mathrm{Fe}$ ratio drops to $\sim 1.7$ in the sludge solids generated from the 3-L LTAD demonstration. ${ }^{3}$ Although the composite sample was prepared from several small samples remaining from the original 3-L sample; the composite sample appears to be representative of the original sample based on the characterization data. 
Table 3-2. Composition of the Sodium Peroxide Fusion Dissolutions of the Initial Washed Sludge Solids from the Composite Sample

\begin{tabular}{|c|c|c|c|c|c|c|}
\hline Analyte & Units & $1^{\text {st }}$ Replicate & $2^{\text {nd }}$ Replicate & Average & $\%$ RSD & Blank \\
\hline Ag & $\mathrm{mg} / \mathrm{kg}$ & $<1.4 \mathrm{E}+02$ & $<1.4 \mathrm{E}+02$ & - & - & $<1.4 \mathrm{E}+02$ \\
\hline $\mathrm{Al}$ & $\mathrm{mg} / \mathrm{kg}$ & $2.36 \mathrm{E}+05$ & $2.39 \mathrm{E}+05$ & $2.37 \mathrm{E}+05$ & $1.0 \%$ & $<5.9 \mathrm{E}+02$ \\
\hline B & $\mathrm{mg} / \mathrm{kg}$ & $<1.2 \mathrm{E}+03$ & $<1.2 \mathrm{E}+03$ & - & - & $<1.2 \mathrm{E}+03$ \\
\hline Ва & $\mathrm{mg} / \mathrm{kg}$ & $6.98 \mathrm{E}+02$ & $6.93 \mathrm{E}+02$ & $6.96 \mathrm{E}+02$ & $0.5 \%$ & $<1.2 \mathrm{E}+02$ \\
\hline $\mathrm{Be}$ & $\mathrm{mg} / \mathrm{kg}$ & $<3.2 \mathrm{E}+01$ & $<3.2 \mathrm{E}+01$ & - & - & $<3.2 \mathrm{E}+01$ \\
\hline $\mathrm{Ca}$ & $\mathrm{mg} / \mathrm{kg}$ & $2.01 \mathrm{E}+04$ & $1.42 \mathrm{E}+04$ & $1.72 \mathrm{E}+04$ & $24 \%$ & $5.57 \mathrm{E}+03$ \\
\hline Cd & $\mathrm{mg} / \mathrm{kg}$ & $4.82 \mathrm{E}+02$ & $4.93 \mathrm{E}+02$ & $4.87 \mathrm{E}+02$ & $1.6 \%$ & $<9.1 \mathrm{E}+01$ \\
\hline $\mathrm{Ce}$ & $\mathrm{mg} / \mathrm{kg}$ & $<1.2 \mathrm{E}+03$ & $<1.2 \mathrm{E}+03$ & - & - & $<1.2 \mathrm{E}+03$ \\
\hline $\mathrm{Cr}$ & $\mathrm{mg} / \mathrm{kg}$ & $1.08 \mathrm{E}+03$ & $8.51 \mathrm{E}+02$ & $9.64 \mathrm{E}+02$ & $17 \%$ & $4.54 \mathrm{E}+02$ \\
\hline $\mathrm{Cu}$ & $\mathrm{mg} / \mathrm{kg}$ & $4.98 \mathrm{E}+02$ & $4.90 \mathrm{E}+02$ & $4.94 \mathrm{E}+02$ & $1.1 \%$ & $1.06 \mathrm{E}+02$ \\
\hline $\mathrm{Fe}$ & $\mathrm{mg} / \mathrm{kg}$ & $1.15 \mathrm{E}+05$ & $1.16 \mathrm{E}+05$ & $1.15 \mathrm{E}+05$ & $0.7 \%$ & $1.89 \mathrm{E}+03$ \\
\hline Gd & $\mathrm{mg} / \mathrm{kg}$ & $<1.2 \mathrm{E}+02$ & $<1.1 \mathrm{E}+02$ & - & - & $<1.1 \mathrm{E}+02$ \\
\hline K & $\mathrm{mg} / \mathrm{kg}$ & $<6.0 \mathrm{E}+03$ & $<5.9 \mathrm{E}+03$ & - & - & $<5.9 \mathrm{E}+03$ \\
\hline $\mathrm{La}$ & $\mathrm{mg} / \mathrm{kg}$ & $4.74 \mathrm{E}+02$ & $4.60 \mathrm{E}+02$ & $4.67 \mathrm{E}+02$ & $2.1 \%$ & $<8.9 \mathrm{E}+01$ \\
\hline $\mathrm{Li}$ & $\mathrm{mg} / \mathrm{kg}$ & $<1.9 \mathrm{E}+02$ & $<1.9 \mathrm{E}+02$ & - & - & $<1.9 \mathrm{E}+02$ \\
\hline Mg & $\mathrm{mg} / \mathrm{kg}$ & $6.71 \mathrm{E}+03$ & $5.26 \mathrm{E}+03$ & $5.98 \mathrm{E}+03$ & $17 \%$ & $1.30 \mathrm{E}+03$ \\
\hline Mn & $\mathrm{mg} / \mathrm{kg}$ & $2.79 \mathrm{E}+04$ & $2.85 \mathrm{E}+04$ & $2.82 \mathrm{E}+04$ & $1.4 \%$ & $<2.8 \mathrm{E}+01$ \\
\hline Mo & $\mathrm{mg} / \mathrm{kg}$ & $<3.3 \mathrm{E}+02$ & $<3.2 \mathrm{E}+02$ & - & - & $<3.2 \mathrm{E}+02$ \\
\hline $\mathrm{Ni}$ & $\mathrm{mg} / \mathrm{kg}$ & $1.11 \mathrm{E}+04$ & $1.12 \mathrm{E}+04$ & $1.11 \mathrm{E}+04$ & $0.8 \%$ & $<1.1 \mathrm{E}+03$ \\
\hline $\mathrm{P}$ & $\mathrm{mg} / \mathrm{kg}$ & $3.43 \mathrm{E}+03$ & $3.75 E+03$ & $3.59 \mathrm{E}+03$ & $6.2 \%$ & $3.86 \mathrm{E}+03$ \\
\hline $\mathrm{Pb}$ & $\mathrm{mg} / \mathrm{kg}$ & $<5.5 \mathrm{E}+02$ & $<5.4 \mathrm{E}+02$ & - & - & $<5.4 \mathrm{E}+02$ \\
\hline$S$ & $\mathrm{mg} / \mathrm{kg}$ & $<1.6 \mathrm{E}+04$ & $<1.6 \mathrm{E}+04$ & - & - & $<1.6 \mathrm{E}+04$ \\
\hline $\mathrm{Sb}$ & $\mathrm{mg} / \mathrm{kg}$ & $<1.1 \mathrm{E}+03$ & $<1.1 \mathrm{E}+03$ & - & - & $<1.1 \mathrm{E}+03$ \\
\hline Si & $\mathrm{mg} / \mathrm{kg}$ & $4.58 \mathrm{E}+03$ & $4.69 \mathrm{E}+03$ & $4.64 \mathrm{E}+03$ & $1.6 \%$ & $<2.6 \mathrm{E}+02$ \\
\hline Sn & $\mathrm{mg} / \mathrm{kg}$ & $<1.0 \mathrm{E}+04$ & $<1.0 \mathrm{E}+04$ & - & - & $<1.0 \mathrm{E}+04$ \\
\hline $\mathrm{Sr}$ & $\mathrm{mg} / \mathrm{kg}$ & $<1.5 \mathrm{E}+03$ & $<1.5 \mathrm{E}+03$ & - & - & $<1.5 \mathrm{E}+03$ \\
\hline $\mathrm{Ti}$ & $\mathrm{mg} / \mathrm{kg}$ & $2.65 \mathrm{E}+02$ & $2.41 \mathrm{E}+02$ & $2.53 \mathrm{E}+02$ & $6.8 \%$ & $2.28 \mathrm{E}+02$ \\
\hline U & $\mathrm{mg} / \mathrm{kg}$ & $2.72 \mathrm{E}+04$ & $2.80 \mathrm{E}+04$ & $2.76 \mathrm{E}+04$ & $2.0 \%$ & $<3.6 \mathrm{E}+03$ \\
\hline V & $\mathrm{mg} / \mathrm{kg}$ & $<1.1 \mathrm{E}+03$ & $<1.1 \mathrm{E}+03$ & - & - & $<1.1 \mathrm{E}+03$ \\
\hline Zn & $\mathrm{mg} / \mathrm{kg}$ & 4.73E+02 & $4.65 \mathrm{E}+02$ & $4.69 \mathrm{E}+02$ & $1.1 \%$ & $7.96 \mathrm{E}+02$ \\
\hline
\end{tabular}

Divide $\mathrm{mg} / \mathrm{kg}$ values by $1 \mathrm{E}+04$ to convert to wt \% dried solids basis 
Table 3-3. Comparison of the Normalized Composition of Washed Solids from the Composite Sample with the Original 3-L Sample

\begin{tabular}{|l|c|c|}
\hline Analyte & $\begin{array}{c}\text { Composite } \\
\text { Sample }\end{array}$ & $\begin{array}{c}\text { Original 3-L } \\
\text { Sample }\end{array}$ \\
\hline $\mathrm{Fe}$ & 1.00 & 1.00 \\
\hline $\mathrm{Al}$ & 2.06 & 2.14 \\
\hline $\mathrm{Mn}$ & 0.24 & 0.24 \\
\hline $\mathrm{U}$ & 0.24 & 0.22 \\
\hline $\mathrm{Ni}$ & 0.10 & 0.09 \\
\hline $\mathrm{Si}$ & 0.04 & 0.06 \\
\hline
\end{tabular}

\subsection{RESULTS OF THE GIBBSITE/BOEHMITE TEST}

Based on the results of the sample analysis data the sludge solids used in the Gibbsite/Boehmite test contained $0.256 \mathrm{~g}$ of $\mathrm{Al}$. This is slightly lower than the $0.3 \mathrm{~g}$ of $\mathrm{Al}$ targeted for the test but reasonably close given the fact that the dry weight and aluminum concentration in the solids was not known at the start of the test. Table 3-4 shows the total mass of $\mathrm{Al}$ and the mass of $\mathrm{Al}$ from gibbsite present in the sludge sample and the four standards used in the test. The last two standards shown in the table contain slightly more than $0.3 \mathrm{~g}$ of $\mathrm{Al}$ but less than $0.3 \mathrm{~g}$ of $\mathrm{Al}$ from gibbsite. The target proportions for the test of $0.3 \mathrm{~g}$ of $\mathrm{Al}$ in $50 \mathrm{ml}$ of $8 \mathrm{M} \mathrm{NaOH}$ were based on conditions needed to dissolve all of the gibbsite in approximately two hours. The presence of additional aluminum in the standards from boehmite should not impact the rate of gibbsite dissolution. From the cold bench top tests conducted using pure gibbsite, pure boehmite, and various mixtures of gibbsite and boehmite, the rate of boehmite dissolution appears to be approximately linear and independent of the ratio of the mass of aluminum to the volume of $8 \mathrm{M} \mathrm{NaOH}$ at $65{ }^{\circ} \mathrm{C}$ over the short duration of the tests.

Table 3-4. Mass of Aluminum in the Sludge Solids and Standards

\begin{tabular}{|l|c|c|}
\hline Analyte & $\begin{array}{c}\text { Total Mass of } \\
\text { Al (g) }\end{array}$ & $\begin{array}{c}\text { Mass of Al (g) } \\
\text { from Gibbsite }\end{array}$ \\
\hline Washed Sludge Solids & 0.256 & - \\
\hline 100\% Gibbsite Std & 0.311 & 0.311 \\
\hline 75\% Gibbsite/25\% Boehmite Std & 0.335 & 0.235 \\
\hline 25\% Gibbsite/75\% Boehmite Std & 0.382 & 0.076 \\
\hline 100\% Boehmite Std & 0.405 & 0.000 \\
\hline
\end{tabular}


Table 3-5 shows the analytical results for the aluminum concentration in the solutions of each of the four standards and the sludge sample over the course of the four-hour test. Figure 3.1 shows a graphical representation of the same data. The data indicates that, for the three standards containing gibbsite, all of the gibbsite dissolved in approximately 2 hours at $65{ }^{\circ} \mathrm{C}$ in $8 \mathrm{M} \mathrm{NaOH}$. The concentration of $\mathrm{Al}$ in solution at 2 hours for those three standards closely matches the expected concentration assuming complete gibbsite dissolution, based on the moles of gibbsite and volume of solution in each bottle. Under the test conditions boehmite dissolved at more than an order of magnitude more slowly than gibbsite. The rate of boehmite dissolution under the test conditions appears to be nearly linear at 1.3E-04 moles/hour. The graph in Figure 3.1 clearly shows the sludge sample contains aluminum that dissolves at a rate similar to the $100 \%$ Boehmite standard. Combined with the XRD data on the original 3-L sample ${ }^{3}$, these results provide substantial evidence that the boehmite form of aluminum predominates in the sludge.

Table 3-5. Measured Aluminum Concentration (M) in Solution from Samples Obtained during the Gibbsite/Boehmite Test

\begin{tabular}{|l|c|c|c|c|c|}
\hline $\begin{array}{l}\text { Time from start } \\
\text { of test (hr) }\end{array}$ & $\mathbf{1 0 0 \% \text { Gibbsite }}$ & $\begin{array}{c}\text { 75\% Gibbsite } \\
\text { 25\% Boehmite }\end{array}$ & $\begin{array}{c}\text { 25\% Gibbsite } \\
\text { 75\% Boehmite }\end{array}$ & $\begin{array}{c}\text { Tank 51H } \\
\text { 100\% Boehmite }\end{array}$ & Sludge Solids* \\
\hline 0 & 0.025 & 0.018 & 0.006 & 0.0001 & 0.0002 \\
\hline 0.5 & 0.135 & 0.089 & 0.032 & 0.001 & 0.005 \\
\hline 1 & 0.194 & 0.139 & 0.050 & 0.003 & 0.010 \\
\hline 1.5 & 0.214 & 0.159 & 0.055 & 0.004 & 0.010 \\
\hline 2 & 0.222 & 0.168 & 0.057 & 0.006 & 0.012 \\
\hline 2.5 & 0.222 & 0.171 & 0.057 & 0.007 & 0.013 \\
\hline 3 & 0.224 & 0.174 & 0.058 & 0.009 & 0.013 \\
\hline 3.5 & 0.225 & 0.174 & 0.058 & 0.010 & 0.014 \\
\hline 4 & 0.225 & 0.175 & 0.059 & 0.012 & 0.014 \\
\hline
\end{tabular}

* The Tank $51 \mathrm{H}$ sludge solids were washed with $0.01 \mathrm{M} \mathrm{NaOH}$ to displace the interstitial supernate prior to the test. 


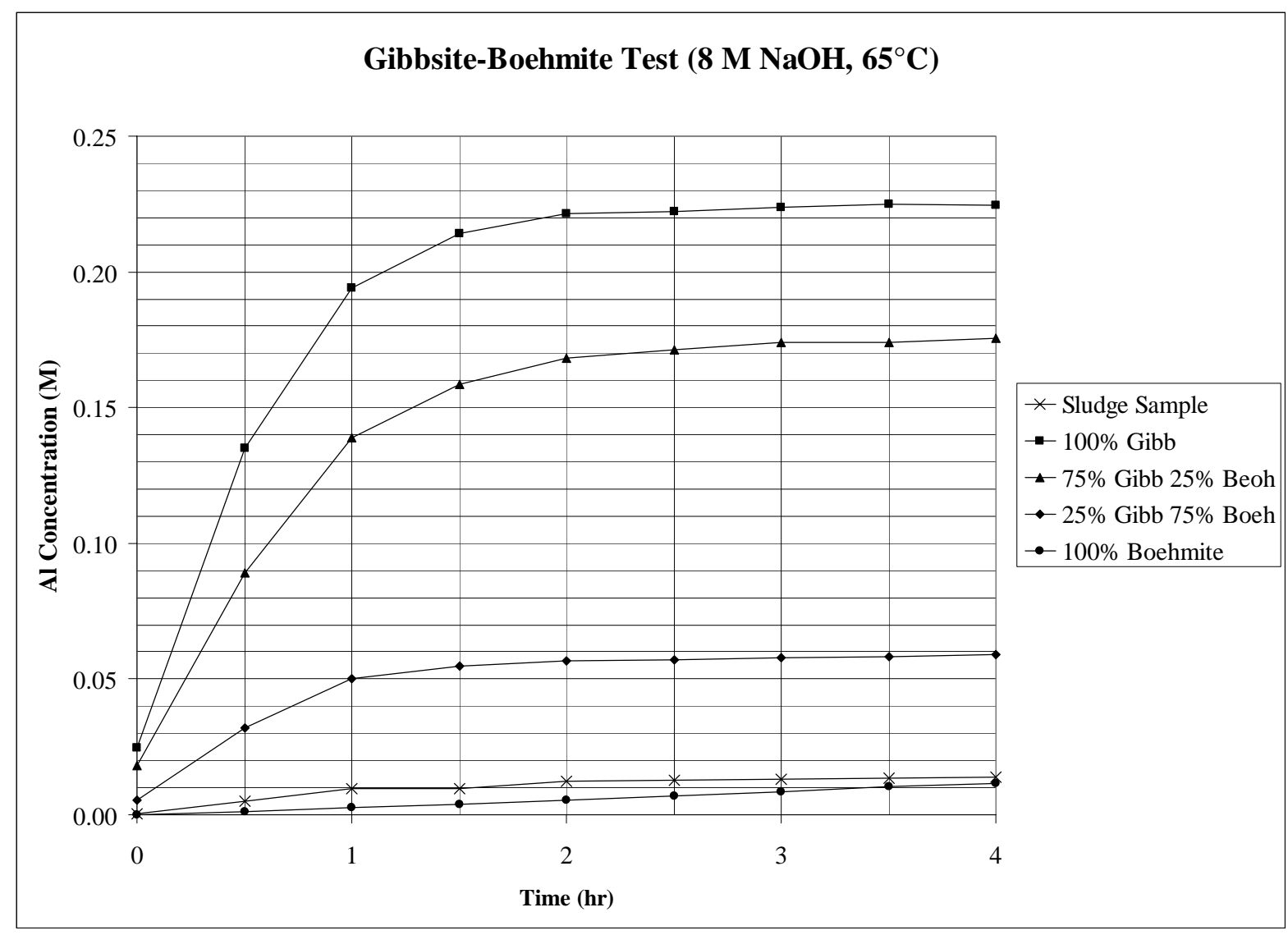

Figure 3.1 Aluminum Concentration as a Function of Time during the Gibbsite/Boehmite Test

The remaining sludge solids from the Gibbsite/Boehmite Test were washed, dissolved and analyzed. Since very little aluminum was dissolved from the sludge based on the samples obtained during the test, the composition remained essentially unchanged from the normalized composition shown in Table 3-3. The Al/Fe ratio dropped slightly from the original sample to 1.99. Table 3-6 shows the normalized composition of the washed sludge solids from the Gibbsite/Boehmite Test.

Table 3-6. The Normalized Composition of Washed Sludge Solids from the Gibbsite/Boehmite Test

\begin{tabular}{|l|c|}
\hline Analyte & $\begin{array}{c}\text { Final Sludge } \\
\text { Solids }\end{array}$ \\
\hline $\mathrm{Fe}$ & 1.00 \\
\hline $\mathrm{Al}$ & 1.99 \\
\hline $\mathrm{Mn}$ & 0.26 \\
\hline $\mathrm{U}$ & 0.24 \\
\hline $\mathrm{Ni}$ & 0.10 \\
\hline
\end{tabular}


WSRC-STI-2008-00366, REV. 0

\subsection{ESTIMATION OF FRACTIONS OF GIBBSITE AND BOEHMITE IN THE TANK 51H SLUDGE SOLIDS}

Since the test data indicates all of the aluminum in the form of gibbsite dissolves in two hours under the test conditions, the fraction of gibbsite in the sludge sample can be estimated from the amount of aluminum in solution measured in the 2-hour sample and the total mass of aluminum in the sludge sample. The total mass of aluminum in the washed sludge solids used in the test can be calculated as follows:

Mass of $\mathrm{Al}$ in sludge solids

$=2.465 \mathrm{~g}$ damp solids $\mathrm{x} 0.44 \mathrm{~g}$ dry solids/g damp solids $\mathrm{x} 0.236 \mathrm{~g} \mathrm{Al} / \mathrm{g}$ dry solids $=0.256 \mathrm{~g} \mathrm{Al}$

The aluminum concentration in solution as measured in the 2-hour sample provides the mass of aluminum in solution resulting from gibbsite dissolution. The small amount of boehmite dissolved in the first two hours will be subtracted using the data from the $100 \%$ Boehmite standard.

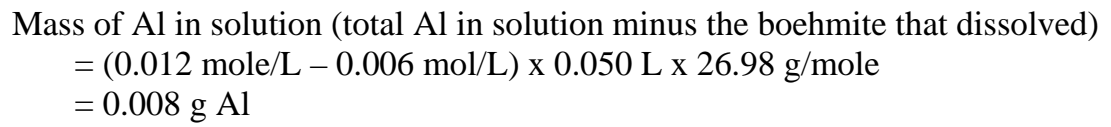

The estimated fraction of aluminum present as gibbsite in the sludge sample can then be calculated from the mass of aluminum in solution and the total mass of aluminum in the sludge sample.

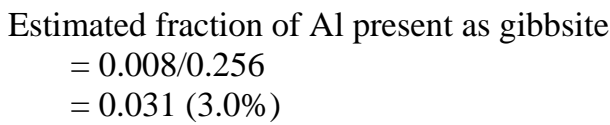

Subtracting the fraction of gibbsite from one yields the estimated fraction of aluminum present as boehmite in the sludge solids (0.97 or $97 \%)$.

\subsection{CONCLUSIONS}

The composite sludge sample prepared from several small samples remaining from the original 3-L sample appears to be representative of the original sample based on the characterization data.

A Gibbsite/Boehmite Test was developed that uses $8 \mathrm{M} \mathrm{NaOH}$ and a temperature of $65{ }^{\circ} \mathrm{C}$ to dissolve aluminum. The soluble aluminum concentration data collected during the test indicates that, for the three standards containing gibbsite, all of the gibbsite dissolved in approximately 2 hours. Under the test conditions boehmite dissolved at more than an order of magnitude more slowly than gibbsite. An estimate based on the soluble aluminum concentration from the sludge sample at two hours into the test indicates the sludge solids contain a form of aluminum that dissolves at a rate similar to the $100 \%$ Boehmite standard. Combined with the XRD data from the original 3-L sample ${ }^{3}$, these results provide substantial 
evidence that the boehmite form of aluminum predominates in the sludge. A calculation from the results of the Gibbsite/Boehmite test indicates the sludge contains $~ 3 \%$ gibbsite and $\sim 97 \%$ boehmite.

The sludge waste in Tank 51H was recently treated under LTAD conditions and a substantial fraction of aluminum (i.e., sludge mass) was removed, avoiding production of over 100 glass canisters in DWPF. ${ }^{1}$ Results of the Gibbsite/Boehmite test indicate that the aluminum in this sludge was in the form of the more difficult to dissolve boehmite form of aluminum. Since boehmite may be the dominant form of aluminum in SRS waste tank sludge, this result suggests that the conditions of the LTAD process can be used to dissolve both the gibbsite and boehmite forms of aluminum in tank sludge and costly tank infrastructure upgrades required for the higher temperature baseline process ${ }^{2}$ can be avoided. However, this conclusion should be confirmed by testing additional waste tank samples. 


\subsection{REFERENCES}

1. J. A. Pike, "Preliminary Results for Low Temperature Aluminum Removal from Sludge Batch 5”, LWO-LWE-2008-00067, Rev. 0, March 24, 2008.

2. J. A. Pike, “Review of SMR Process Development Since CD-0”, LWO-LWE-200800117, Rev. 0, May 14, 2008.

3. M. S. Hay, J. M. Pareizs, C. J. Bannochie, M. E. Stone, D. R. Click, D. J. McCabe, "Characterization and Aluminum Dissolution Demonstration with a 3 Liter Tank 51H Sample”, WSRC-STI-2007-00697, February 2008.

4. $\quad$ Private communication from Addai-Mensah to D.J. McCabe, April 13, 2007.

5. E. T. Ketusky, “Dissolution of Tank 51 Sludge”, HLE-TTR-2007-018, Rev. 1, May 21, 2007.

6. M. S. Hay, D. J. McCabe, “Task Technical and Quality Assurance Plan for Dissolution of Tank 51 Sludge” WSRC-TR-2007-00176, Rev. 0, May 21, 2007.

7. K. Adu-Wusu, D. J. McCabe, “Aluminum Dissolution and Sludge Settling” WSRCSTI-2008-00208, Rev. 0, April 18, 2008. 